\title{
REORIENTASI PEMIKIRAN AL-GHAZALI TENTANG MASLAHAH MURSALAH DENGAN PEMBARUAN HUKUM ISLAM
}

\author{
Ahmad Munif Suratmaputra \\ IIQ Jakarta \\ amunif99@yahoo.com
}

\begin{abstract}
Abstrak
Wahyu terbagi menjadi dua istilah yakni wahyu matluw, yaitu al-Qur'an al-Karim, dan wahyu gairu matluw, yaitu asSunnah dan al-Hadis. Kehadiran hukum Allah atau hukum Islam (ahkam syar'iyyah) yang harus dijadikan pedoman dan acuan untuk mewujudkan kemaslahatan bagi umat manusia. Atas dasar ini, para pakar fiqh dan ushul fiqh telah konsensus bahwa maslahat atau kemaslahatan merupakan tujuan inti pensyari' atau hukum Islam : sehingga muncullah ungkapan yang sangat populer dikalangan mereka : فثم حكم الل أينما كانت المصلحة (dimana ada maslahat, disanalah ada hukum Allah).

Menyadari bahwa tidak semua masalah kehidupan ini hukumnya ditemukan didalam al-Qur'an dan as-Sunnah/Hadis, Islam meletakkan prinsip-prinsip umum dan kaidah-kaidah dasar yang dapat dijadikan oleh ahl az-Zikri (para mujtahid) untuk mengembangkan hukum Islam dan memecahkan masalahmasalah baru melalui ijtihad. Salah satu prinsip umum dan kaidah dasar yang diletakkan oleh Islam ialah bahwa tujuan pokok tujuan pensyar'i atau hukum Islam adalah untuk mewujudkan kemaslahatan (jalb al-masalaih). Dari prinsip inilah prinsip para imam mujtahid dan pakar ushul fiqh mengembangkan hukum Islam dan berusaha memecahkan masalah-masalah baru yang dihadapi oleh umat Islam yang belum ada penegasan hukumnya di dalam al-Qur'an dan as-Sunnah melalui qiyas, istihsan, maslahah mursalah dan sad az-Zari'ah.

Al-Ghazali (450-505 H.) sebagai pakar ushul fiqh dari kalangan madzhab Syafi'i, mempunyai pemikiran-pemikiran yang cukup menarik tentang maslahah mursalah. Pandangannya tentang maslahah mursalah merupakan jalan tengah antara pihakpihak yang sama sekali tidak mempergunakan maslahah mursalah sebagai dalil hukum dan mereka yang begitu berani dalam menjadikan maslahah mursalah.
\end{abstract}

Kata Kunci : Reorientasi; Al-Ghazali; Maslahah Mursalah 


\section{A. Pendahuluan}

Pembaruan hukum Islam ditemukan melalui beberapa literatur, antara lain : arti pembaruan dalam bahasa bahasa Indonesia. Pembaruan berasal dari kata baru dnegan mendapatkan awalnya pe dan akhiran an. Dalam bahasa Indonesia, kata baru mengandung beberapa arti. Di antaranya ialah belum pernah ada sebelumnya, belum pernah didengar sebelumnya, belum pernah dipakai, permulaan, segar, dan modern. ${ }^{1}$

Arti kata "baru" itu sesuatu yang baru memang belum pernah ada sebelumnya. Oleh karena belum pernah ada maka belum pernah dilihat, belum pernah didengar, belum pernah dipakai. Munculnya sesuatu yang baru biasanya terasa lebih segar atau menimbulkan suasana segar. Hal ini sejalan dengan ungkapan kata-kata hikmat al-jadid laziz, yang baru itu lezat dan nikmat. Sesuatu yang baru juga sering dianggap modern. Kemudian dalam kamus tersebut disebutkan, memperbaruhi berarti memperbaiki supaya menjadi baru, mengulangi sekali lagi, memulai pembaruan artinya proses, perbuatan, cara memperbarui. ${ }^{2}$

Dari beberapa arti kata dan pembaruan tersebut kalau hal ini kepada hukum Islam, maka pembaruan hukum Islam dapat di artikan sebagai sesuatu upaya dan perbuatan melalui proses tertentu (dengan penuh kesungguhan) yang dilakuka oleh mereka yang mempunyai kompetensi dan otoritas dalam pengembangan hukum Islam (mujtahid) dengan cara-cara tertentu (berdasarkan kaidah-kaidah istinbat/ijtihad yang dibenarkan) untuk menjadikan hukum Islam dapat tampil lebih segar dan nampak modern (tidak ketinggalan zaman). Inilah yang dalam istilah usul al-figh dikenal dengan ijtihad ${ }^{3}$ sebagaimana nanti akan dikaji. Itulah yang di maksud dengan pembaruan hukum Islam dalam kajian ini.

${ }^{1}$ Depdikbud, Kamus Besar Bahasa Indonesia, cet. Ke-7, edisi ke-2 (Jakarta; Balai Pustaka, 1996), 96.

${ }^{2}$ Depdikbud, Kamus Besar Bahasa Indonesia, cet. Ke-7, edisi ke-2 (Jakarta; Balai Pustaka, 1996), 96.

${ }^{3}$ Oleh usuliyyah, ijtihad dirumuskan dengan ungkapan: إستفراغ الفقهية لتحصيل ظن بكمم شرعى Artinya : "Pengertian segala potensi ilmiah yang dilakukan oleh seorang faqih unyuk mendapatkan hukum Islam tingkat zann”. Lihat alAsnawi, Nihayah al-Sul, juz.4 (Beirut: 'Alam al-Kutub, 1982), 525. 
Dengan demikian, pembaruan hukum Islam yang dilakukan tidak mempunyai otoritas dan kompentensi dalam pengembangan hukum Islam-tidak memenuhi kualifikasi sebagai mujtahid-atau tidak dilakukan berdasarkan aturan main-tidak berdasarkan kaidah-kaidah ijtihad/istinbat yang telah diakui kebenaranya oleh para pakar hukum Islam (fuqaha' dan usuliyyin)-tidak dapat dinamakan sebagai pembaruan hukum islam. Dan mayoritas ulama menyatakan, ijtihad itulah hakikat tajdid (pembaruan) di dalam hukum Islam. ${ }^{4}$

Dalam bahasa Arab, ada dua kosa kata yang sering di pakai oleh para ahli sejarah yang menulis tentang perkembangan pemikiran dalam Islam. Dua kosa kata itu ialah tajdid dan islah. Dr. Muhammad al-Bah dalam bukumnya al-fiqh al-islam al-hadis mempergunakan kedua kata tersebut dengan tanpa dibedakan artinya. Kedua-keduanya diartikan pembaruan. Dr. Bustami Muhammad Sa'ad dalam bukunya mafhum tajdid ad-din mempergunakan kata tajdid dengan arti pembaruan. Sementara para muhaddisin dan komentatornya seperti Ibn al-Asir, anNawawi, as-Suyuti, dan lain-lain banyak mempergunakan kata tajdid dengan arti pembaruan.

Tajdid merupakan bentuk masdar dari kata jaddadayujaddidu-tajdidan ${ }^{5}$ Jaddada-yujaddidu 6 artinya "memperbarui"; dan tahdid ${ }^{7}$ artinya "pembaruan". Kata jaddada-yujaddidu" merupakan fi'il sulasi mazid (kata kerja yang huruf asalnya tiga kemudian mendapatkan imbuhan). Ia berasal dari fi'il sulasi mujrrad (kata kerja yang huruf asalnya terdiri dari tiga huruf), yaitu jadda-yajiddu/yajuddu-jaddan/jiddan-jadadan-jadidan ${ }^{9}$, yang artinya "baru". Dalam bahasa Arab disebutkan bahwa jadid aks' al-Qadim ${ }^{10}$ (jadid adalah kebalikan dari qadim). Qadim artinya "lama", dengan demikian jadid artinya "baru".

${ }^{4}$ Bustami Muhammad Sa'ad, Mafhum Tajdid ad-Din (Kuwait : Dar adDa'wah, t.t), 26-27.

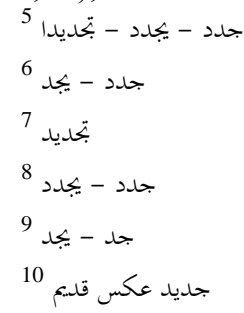


Kata tajdid yang artinya pembaruan diambil dari kata jadid ini. Lebih jauh dalam kamus Arab disebutkan ungkapan jaddadahu ai shayyarahu jadidan ${ }^{11}$, artinya menjadikan sesuatu menjadikan baru. Kata jaddada artinya sama dengan istajadda ${ }^{12}$, artinya sesuatu menjadi baru. ${ }^{13}$

Kata islah ${ }^{14}$ merupakan bentuk masdar dari kata kerja aslaha-yuslihu $^{15}$ yang artinya memperbaiki atau perbaikan. Ia berasal dari sulasi mujarrad salahah-yasluhu-salahan ${ }^{16}$ yang artinya baik, layak, patut, dan memberi faedah/manfaat. Dari akar kata salah ini pula kata maslahah (mursalah) dan istislah diambil. Dalam awal bab kedua telah disinggung bahwa kata masalah yang berasal dari kata salah artinya identik dengan kata manfaat.

Dari sini dapat difahami betapa eratnya hubungan antara kata salah, istislah, dan maslaha (mursalah). hal ini mengingatkan bahwa upaya mencari kejelasan hukum suatu masalah yang dihadapi mujtahid melalui metode istislah atau berdasarkan kondisi positif obyektif berupa maslaha mursalah itu benar-benar dimaksudkan untuk mewujudkan salah (kebaikan/manfaat/faedah) dan sekaligus merupakan islah (perbaikan dan pembaruan) hukum Islam atas dasar ini kiranya tidak berlebih-lebihan kalau dikatakan bahwa istislah yang merupakan salah satu metodologi ijtihad itu pada hakikatnya adalah bagian dari at-tajdid fi al-ahkam asy-syar'iyyah (pembaruan hukum Islam) itu sendiri.

Dalam sejarah perkembangan pemikiran Islam seperti telah disinggung diatas kata islah dan tajdid sering dipakai secara berdampingan dengan pengertian yang sama, yaitu pembaruan. Di antaranya ialah Dr. Muhammad al-Bahi dalam bukunya $a l-f i k r$ al-islami al-Hadis. Sebagaian dibedakan arti islah dari tajdid, islah berarti permunian, sedangkan tajdid berarti pembaruan.

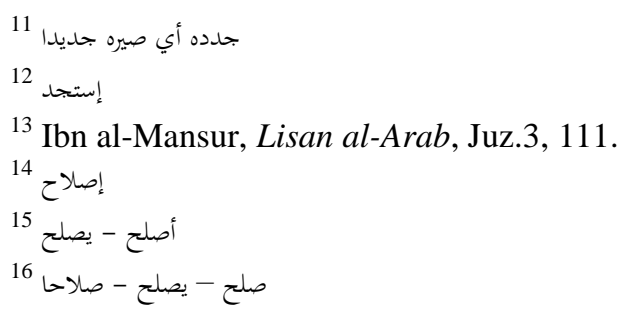


Tokoh semacam Ibn Taimiyah lebih tepat disebut sebagai muslih (pemurnian, tokoh yang berusaha keras memurnikan kembali ajaran Islam), bukan mujaddid (pembaru). Sementara tokoh semacam Muhammad Abduh lebih tepat disebut sebagai mujaddid (tokoh pembaru atau pembaruan).

Kalau kembali kesumber pokok hukum Islam, yaitu alQur'an dan sunnah/hadis, maka akar kata kedua kata tersebut (tajdid dan islah) akan ditemukan dengan frekuensi penggunaan yang cukup tinggi dalam berbagai kesempatan.

Untuk akar kata tajdid misalnya ditemukan didalam alQur'an sebanyak 9 tempat. Diantaranya : Surat Ibrahim [14]: 19 dan surat Fatir [35]: 16), Surat al-Israh' [17]: 49 dan 98, sebagaimana redaksinya dijelaskan dibawah ini :

$$
\text { إِن يَشَأْ يُذْهِبْكُمْ وَيَأْتِ بِنَلْقِق جَدِيدٍ }
$$

Artinya: "Kalau Allah menghendaki, maka Allah akan melenyapkan kamu dan mengganti dengan generasi yang baru” (QS. Ibrahim [14]: 19 dan Q.S Fatir [35]: 16).

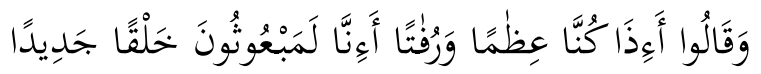

Artinya: "dan mereka berkata: Apakah bila kami telah menjadi tulang belulang dan bendayang hancur, kami akan dibangkitkan kembali sebagai makhliq yang baru” (Q.S al-Israh' [17]: 49 dan 98).

Untuk akar kata islah dipergunakan di dalam al-Qur'an dalam jumlah yang lebih banyak lagi, yaitu sebanyak 180 kali. Diantaranya: Surat al-A'raf [7]: 56 dan 85, Surat al-Baqarah [2]: 220, sebagaimana firmannya dibawah ini:

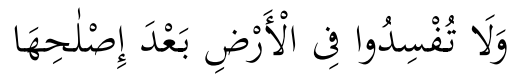

Artinya: "Janganlah kamu membuat kerusakan dimuka bumi setelah Allah memperbaikinya”. (QS. al-a'raf [7]: 56 dan $85)$.

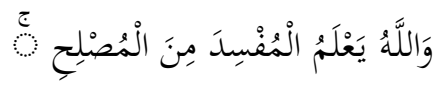

Artinya: "Allah mengetahui orang yang berbuat kerusakan dari orang yang berbuat kebaikan." (Q.S al-Baqarah [2]: 220) 
Untuk akar kata tajdid di dalam as-Sunnah (hadis), dapat diketemukan antara lain: Hadis riwayat Abu Dawud ${ }^{17}$ dan Hadis riayat Ahmad bin Hanbal ${ }^{18}$ sebagaimana dijelaskan dibawah ini :

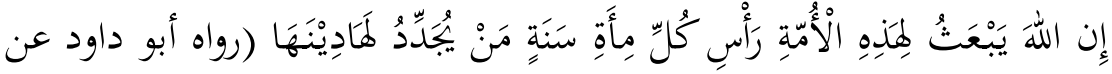

$$
\begin{aligned}
& \text { سليمان بن داود المهرى عن ايى وهب عن سعيد بن أبى أيوب عن شرحبل بن } \\
& \text { يزيد المعافرى عن أبى علقمة عن أبى هريرة) }
\end{aligned}
$$

Artinya: "Sesungguhnya Allah akan membangkit untuk umat ini (umat Islam) pada penghujung setiap seratus tahun (satu abad) orang-orang yang memperbaruhi pemikiran agama mereka." (Diriwayatkan oleh Abu Dawud dari Sulaiman bin Dawud al-Mahri dai Ibn Wahb dari Sa'id bin Abi Ayub dari Syarahbil bin Yazid al-Mu'afiri dari Abi 'Alqamah dari Abi Hurairah).

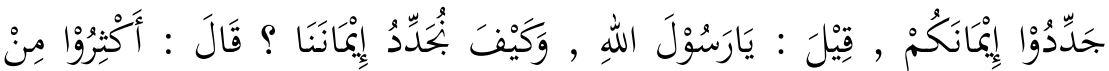

$$
\begin{aligned}
& \text { قَوْلِل لاَ إلَهَ إلااللهُ . (رواه أحمد بن حنبل عن سليمان بن داود الطيالسى عن }
\end{aligned}
$$

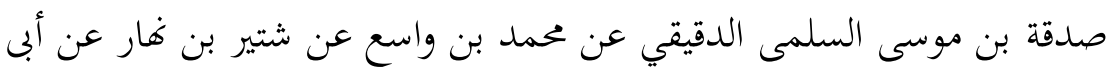$$
\text { هريرة) }
$$

Artinya: "Perbaruilah imamu! Rasulullah ditanya, bagaimana kami memperbarui imanmu? Rasul menjawa: "Perbanyaklah membaca la ilaha illallah." (Diriwayatkan oleh Ahmad bin Hanbal dari Sulaiman bin Dawud at-Tayalisi dari Syutair bin Nahar dari Abi Hurairah).

Sedangkan mengenai kata islah dalam as-Sunnah ditemukan antara lain: Hadis riwayat Bukhari bahwa Rasulullah berdoa $^{19}$ dan Hadis Muslim tentang do'a Rasulullah Saw ${ }^{20}$, sebagaimana disabdakan dibawah ini :

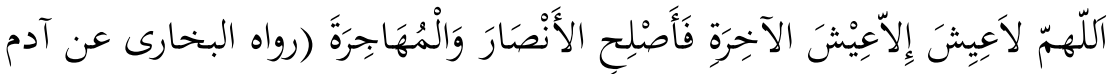

$$
\begin{aligned}
& \text { عن شعبة عن أبى إياس عن أنس بن مالك) }
\end{aligned}
$$

17 Al-Minawi, faid al-Qadir, juz.2 (Cairo: Maktabah at-Tijariyah alKubra, 1938), 282. Al-Albani, Silsilah al-Ahadis as-Sahihah (Beirut: alMaktab al-Islami, 1972), 601. 359.

${ }^{18}$ Ibn Hanbal, al-Musnad, juz.2 (Beirut: al-Maktab al-Islami, 1978),

${ }^{19}$ Bukhari, Sahih al-Bukhari, juz.2 (Beirut: Dar al-Fikr, t.t), 311.

${ }^{20}$ Sayyid Ahmad al-Hasyimi, Muhtar al-Ahadis an-Nabawiyyah, cet. Ke-12 (Beirut: Dar al-Fikr, t.t), 29-30. 
Artinya: "Ya Allah, perbaikilah untukku agamaku yang mejadi pelindung segala urusanku. Perbaikilah untukku duniaku yang menjadi tempat kehidupanku. Perbaikilah untukku akhiratku yang menjadi tempat kembaliku. Jadikanlah kehidupan ini sebagai tambahan segala macam kebaikan untukku.dan jadikanlah mati sebagai kenikmatan kami keluar dari segala macam keburukan." (Hadis diriwayatkan oleh Bukhari dari Ibrahim bin Dinar dari Abi Qutn Amr bin Haisam al-Quta'i dari Abdul Aziz bin Abi Salamah al-Majisyun dari Qudamah bin Musa dari abi Salih as-Saman dari Abi Hurairah).

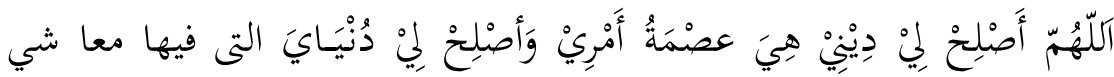

$$
\begin{aligned}
& \text { وأصلح لى آخرتى التى إليها معادي واجعل الحياة زيادة لم في كلى خير خير واجعلى } \\
& \text { الموت راحة لى من كل سر (رزاه مسلم عن إبرهيم بـ دينار عن أبى قطن عمرو إحياه }
\end{aligned}
$$

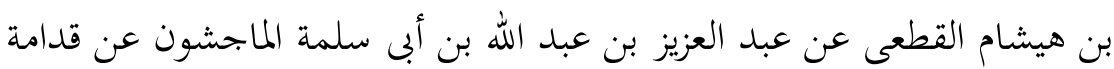

$$
\begin{aligned}
& \text { بن موسى عن أبى صالح السماى عن أبى عريرة) }
\end{aligned}
$$

Artinya: "Ya Allah, perbaikilah untukku agamaku yang menjdai pelindung segala urusanku. Perbaikilah untukku duniaku yang menjadi tempat kehidupanku. Kehidupan ini sebagai tambahan segala macam kebaikan untukku. Dan jadikanlah sebagai kenikmatan kami keluar dari segala macam keburukan." (Hadis diriwayatkan oleh Bukhari dari Ibrahim bin Dinar dari Abi Qutn Amr bin Haisam al-Quta'i dari Abdul Aziz bin Abi Salamah al-Majisyum dari Qudamah bin Musa dari Abi Salih as-Saman dari Abi Hurairah).

Dengan mengacu kepada pengertian tajdid dan islah sebagaimana dapat dilacak sumber akar katanya dalam al-Qur'an dan as-Sunnah (hadis) tersebut maka pembaruan didalam Islam secara umum adalah apa yang dimaksud dengan tajdid dan islah dalam bahasa Arab tersebut. Sedangkan secara khusus, yakni dalam kaitannya dengan hukum Islam maka maksud dalam artikel ini, pembaruan adalah apa yang dalam istilah usul al-fiqh dikenal dengan ijtihad sebagaimana yang akan dikaji. 


\section{B. Pembaruan Hukum Islam sebagai Kebutuhan}

Dengan wafatnya Rasulullah Saw dan diakuinya Islam sebagai agama yang telah lengkap dan sempurna pokok-pokok dan prinsip-prinsip ajarannya oleh Syar' $i$ atau Allah $^{21}$ sebagai pemegang sultah at-tasyri'-pemegang hak prerogative dan otoritas untuk menetapkan hukum Islam-maka wahyu telah berhenti. Ini berarti bahwa al-Qur'an dan as-Sunnah sebagai sumber dalil pokok hukum Islam tidak akan menambah lagi.

Teks-teks ayat al-Qur'an telah tuntas dan demikian juga teks-teks as-Sunnah atau hadis Nabi telah terhenti tidak akan muncul baru lagi. Sementara itu kehidupan umat manusia terus berkembang dengan begitu pesatnya. Aneka macam problematika kehidupan bermunculan. Kasus-kasus baru pada zaman dahulu belum pernah terjadi kini datang silih berganti, dan tantangan kehidupan pun kian menjadi. Kesemuanya ini memerlukan pemecahan dan harus didudukan bagaimana status hukumnya didalam Islam.

Dalam kondisi seperti itu jelas tidak semua persoalan kehidupan yang dihadapiu oleh umat manusia dapat ditemukan hukumnya didalam al-Qur'an dan as-Sunnah atau hadis. Jangankan untuk hari ini atau masa yang akan datang nanti, hal semacam itu sudah mulai muncul dan terasa begitu Rasululah wafat. Itulah masalah yang pertama kali dihadapi oleh para sahabat.

Dengan demikian pembaruan hukum dalam arti keharusan ada dikalangan umat Islam yang berani melakukan ijtihad baik dalam rangka tatbiq an-nusus-menerapkan dan mengaplikasikan apa yang sudah ada penegasannya dalam teks-teks al-Qur'an dan as-Sunnah (hadis) sesuai dengan fakta yang ada dilapangan-, atau ijtihad dalam arti menemukan status hukum masalahmasalah baru yang memang masa sekali belum disinggung oleh al-Qur'an dan as-Sunnah (hadis) jelas merupakan suatu keharusan kebutuhan yang mendesak. Kalau boleh di-tamsil-kan bahwa hukum Islam itu laksanakan, maka adanya air bersih yang menompang kehidupannya itu multak diperlukan. Tiada lain air bersih itu adalah pembaruan atau ijtihad yang menjadi jiwa semangat, dan rukun Islam. Jadi tanpa pembaruan atau ijtihad hukum Islam bukan saja akan berhenti, beku, dan jumud, jelas akan mati, laksana ikan yang dipisahkan dari air bersih yang menjadi tempat kehidupan.

\footnotetext{
${ }^{21}$ Q.S. al-Maidah [3] : 9.
} 
Berdasarkan itu maka ulama-ulama Hanabilah, Imam Abi Ishaq dan Zubairi dari Syafi'iyyah berpendapat tidak boleh terjadi suatu masa yang dilalui umat kosong dari mujtahid. ${ }^{22}$

Nampaknya syari' sengaja mengatur demikian. Sebab jika setiap persoalan kehidupan pasti langsung ada jawabannya didalam al-Qur'an dan as-Sunnah dapat dibayangkan betapa banyak teks nass al-Qur'an dan as-Sunnah atau hadis yang harus disediakan. Al-Qur'an jelas tidak cukup hanya terdiri dari 30 juz, 114 surat, 6666 ayat. Demikian juga halnya sunnah atau hadis perlu lebih banyak lagi.

Tentu tidak tepat, kalau al-Qur'an dan as-Sunnah atau hadis selaku sumber atau dalil pokok harus lebih banyak lagi memuat teks-teks hukum. Selain merepotkan, tidak praktis, juka akan terlampau besar hormatnya lebih dari itu, justru dengan demikian al-Qur'an dan as-Sunnah atau hadis selaku sumber atau dalil asasi hukum Islam akan kehilangan elastisitas, fleksibelitas, dan daya kelenturannya.

Menyadari hal itu maka al-Qur'an dan as-Sunnah atau hadis telah meletakkan dasar-dasar pokok prinsip-prinsip umum yang dapat dijadikan landasan oleh ahl-az-zikri atau ulama para ahli untuk mengembangkan hukum Islam dikemudian hari dan memecahkan masalah-masalah baru yang umat. Rasulullah Saw pun melatih para sahabatnya selaku pengibar panji-panji Islam sepeninggal beliau untuk melakukan ijtihad dalam rangka menemuan status hukum masalah terjadi ditengah-tengah masyarakat.

Hal ini dimaksudkan oleh Rasulullah Saw agar nanti sepeninggal beliau para sahabat telah terlatih dan terbiasa melakukan ijtihad untuk memecahkan masalah-maslah baru yang dihadapiyang memerlukan pemecahan hukum. Dengan demikian maka hukum Islam akan tetap eksis, dan tidak akan terjadi ditengah-tengah masyarakat adanya permasalahan baru yang muncul kemudian tidak terselesaikan dengan baik atau dengan kata lain tidak diketahui hukumnya sepanjang kajian Islam.

${ }^{22}$ Al-Kamal ibn al-Hammam, at-Tahrir, Juz.4 (t.tp : Dar al-Fikr, t.t), 340. 
Al-Qur'an selain meletakkan prinsip-prinsip dasar yang dapat dijadikan pendoman dan acuan oleh ahl az-zikri untuk mengembangkan hukum Islam, juga memerintahkan ahl az-zikri untuk melakukan ijtihad. Hal itu antara lain dapat kita simak dari : Q.S an-Nisa' [4]:59, Q.S an-Nisa' [4]:83, Q.S al-Hasyr [59] : 2, sebagaimana diredaksikan di bawah ini :

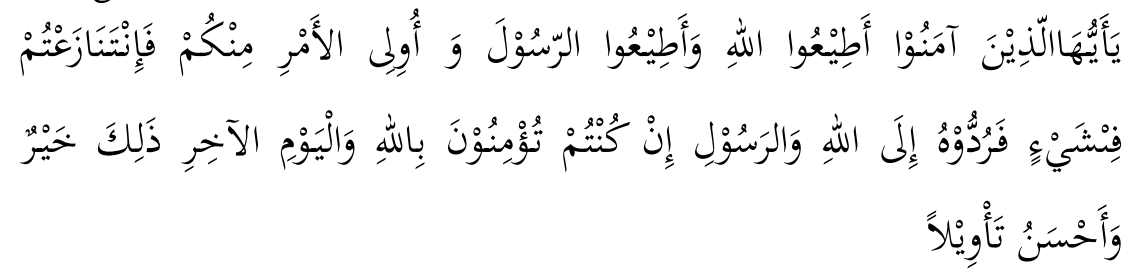

Artinya: "Hai orang-orang yang beriman taatlah kepada Allah dan taat kepada Rasul dan ulil amri diantara kamu. Apabila kamu berselisih tentang suatu maka kembalikanlah kepada Allah dan Rasul, apabila kamu beriman kepada Allah dan hari akhir. Yang demikian itu lebih baik (bagimu) dan lebih bagus akibatnya." (Q.S. an-Nisa' [4]:59).

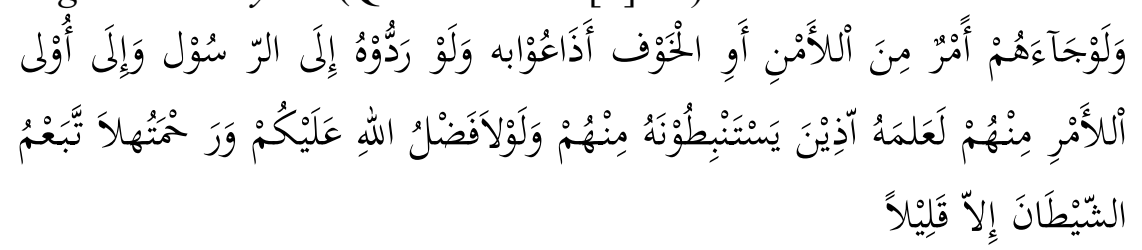

Artinya:"Apabila datang kepada mereka suatu berita tentang keamanan atau ketakutan, mereka lalu menyiarkannya. Dan kalau mereka menyerahkannya kepada Rasul dan ulil-amri di antara mereka, tentulah orang-orang yang ingin mengetahui kebenarannya akan dapat mengetahuinya dari Rasul dan ulilamri itu. Kalaulah tidak karena karunia dan rahmat Allah niscaya kamu akan mengetahui syaitan, kecuali sebagai kecil”. (QS. an-Nisa' [4]:83).

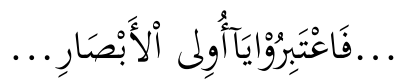

Artinya: "Maka ambilah pelajaran wahai orang-orang yang mempunyai pandangan (mata hati)." (Q.S al-Hasyr [59] : 2). 
Demikian juga Rasulullah bukan saja melatih para sahabat untuk melakukan ijtihad pada saat diperlukaan, tetapi memperlukan memberikan landasan kokoh bagi legitimas ijtihad.

Beberapa hadis dibawah ini menunjukkan hal tersebut yakni : Hadis riwayat Abu Dawud ${ }^{23}$ dan Hadis Muslim ${ }^{24}$, sebagaimana disabdakan dibawah ini :

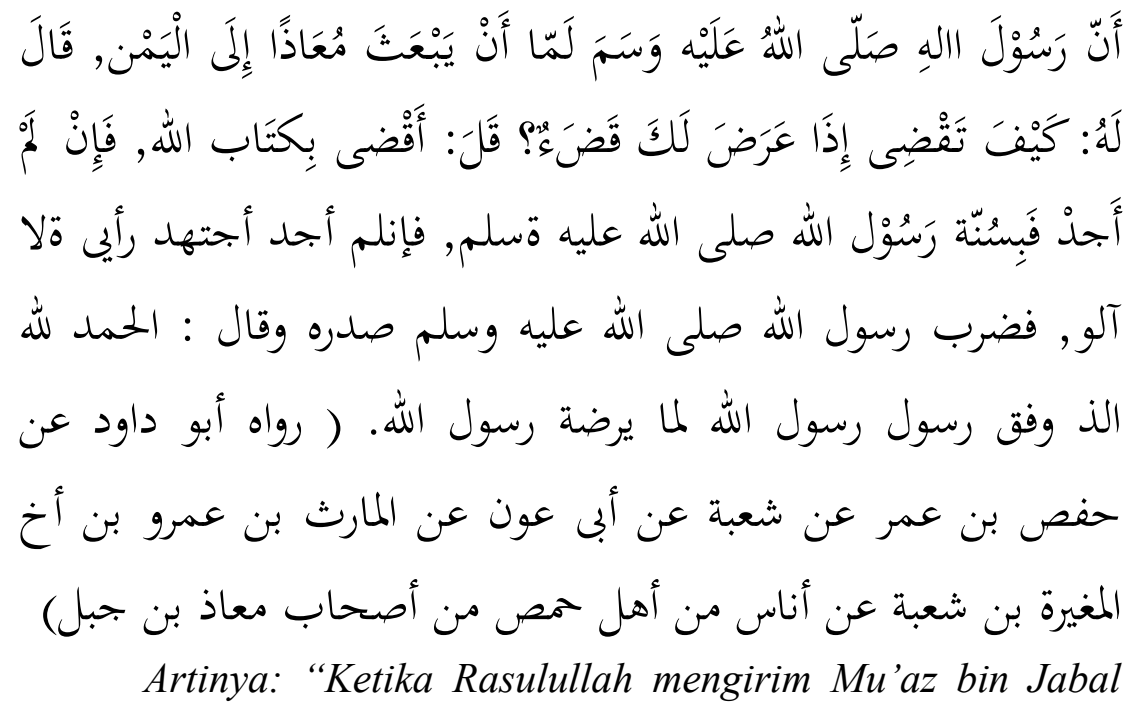
Yaman (untuk menjadi hakim) beliau bertanya: Bagaimana engkau memutuskan perkara apabila engkau menghadapi persoalan yang perlu diselesaikan?'. Mu'az menjawab: 'Aku akan memutuskannya berdasarkan Kitabullah. Dan bila tidak aku temukan maka aku akan memutuskannya berdasarkan Sunnah Rasulullah. Bila tidak aku temukan maka aku akan memutusknnya berdasarkan sunnah Rasulullah. Bila tidak aku temukan maka aku kan berijtihad secara saksama'. Kemudian Rasulullah menepuk dada Mu'az dan berkata: 'Segala puji bagi mu yang telah memberi taufik kepada utusan Rasulullah kepada apa-apa yang diridai oleh Rasulullah."(Diriwayatkan oleh Abu Daud dari Hafs bin Umar dari Syu'bah dari Abi 'Aun dari alHaris ibn 'Amr dari kemenakan al-Mugirah bin Syu'bah dari para sahabat Muaz bin Jabal).

\footnotetext{
${ }^{23}$ Abu Dawud, Sunan Abi Dawud, juz.2 (Beirut: Dar al-Fikr, t.t), 272.

${ }^{24}$ As-San'Ani, Subul as-Salam (t.tp : Dar al-Fikr, t.t.), 118.
} 
إذا حكم الجحاكم فاجتهد ثم أصاب فله أجران فإذا حكم واجتهد ثم أخطأ فله

أجر واحد. (رواه مسلم عن يهيى بـ يهيى التيمى عن عبط العزيز بن محمد عن

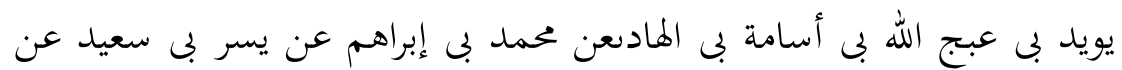

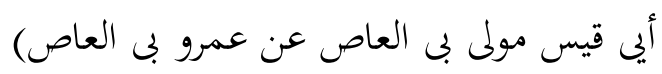

Artinya: "Apabila seorang hakim ingin memutuskan perkara lalu ia berijtihad dan ijtihadnya itu benar maka ia memperoleh dua pahala (pahala ijtihad dan pahala kebenarannya). Dan apabila hakim ini ingin memutuskan perkara, kemudian ia berijtihan ternyata salah maka ia akan dapat satu pahala (pahala ijtihadnya saja)". (Diriwayatkan oleh Muslim dari Yahya bin Yahya At-taiami dari Abdul Aziz bi Muhammad dari Yazid bin amdullah bin Usamah bin alHadi dari Muhammad bin Ibrahin dari YUsr bin Sa'id dari Abi Qais (hamba sahaya 'Amr bin 'As dari 'Amr bin 'As.)

Kenyataannya, sepeninggalan Rasulullah Saw banyak masalah baru yang muncul yang dahulu di zaman Rasullah Saw belum pernah ada. Oleh karna para sahabat telah berlatih menyelesaikan masalah-masalah baru melalui ijtihad berkat dididikan Rasullulah maka kesemuanya itu dapat di selesaikan dengan baik oleh para sahabat.

Bahkan begitu Rasullulah wafat langsung muncul masalah besar yang segera di selesaikan oleh para sahabat, yaitu siapa yang harus menggantikan Rasullulah sebagai kepara negara atau khalifah. Inilah yang oleh sebagian penulis di katakan bahwa masalah yang pertama kali muncul begitu Rasullulah wafat adalah masalah politik. Kenapa hal ini terjadi? Sebab sebelumnya Rasullulah wafat, beliau sengaja tidak menunjuk siapa penggantinya.

Nampaknya Rasullulah sudah yakin bahwa para sahabatnya yang telah sekian lama dididik, dibina, dan digembleng akan mampu menyelesaikan masalah apapun yang di hadapinya. Setelah terjadi diskusi yang cukup menegangkan dan mereka berijtihad maka di temukanlah hadis al-a'immah min Quraisy, pemimpin itu harus dari suku Quraisy. Namun hadis ini semata belum menyelesaikan persoalan. Sebab bukankah tokohtokoh atau sahabat senior dari Quraisy itu cukup banyak, jadi siapa orangnya yang harus di pilih. 
Merekapun terus berijtihad untuk mencari penyelesaian hukum. Akhirnya pun di temukan petunjuk atau dalil lain bahwa ketika Rasullulah sakit keras dan tidak kuat lagi mengimami di masjid, beliau menunjuk Abu Bakar as-Siddiq agar menjadi imam shalat di masjid.

Bedasarkan analog terhadap petunjuk Rasulullah kepada Abu Bakar untuk menjadi imam shalat inilah lalu para sahabat mengambil keputusan bahwa Abu Bakarlah yang layak menggantikan Rasullulah menjadi Khalifah. Maka munculah ungkapan para sahabat "Rasulullah telah merestui Abu Bakar untuk mengurus urusan agama. Apakah rela menerima Abu Bakar untuk mengurus kehidupan"? ${ }^{25}$

Dengan keberanian para sahabat untuk tampil melakukan ijtihad dalam masalah yang tidak ada penegasan lansung dari nass, terpecahkanlah masalah besar yang di hadapi mereka pada waktu itu. Dapat dibayangkan jika masalah itu tidak segera di selesaikan dengan baik, maka jelas akan menjadi krisis politik yang terus berkepanjangan. Pada zaman Rasulullah masih hidup al-Qur'an belum sempat di kondifikasikan, di tulis dalam satu mushaf. Temuan utama untuk menjaga otentitas dan orisinalitas serta kemurnian al-Qur'an adalah hafalan para qurra'. Tulisan alQur'an masih beserakan di beberapa pelepah kurma, kulit binatang, kulit kayu, batu tipis, tulang dan lain sebagainya

Pada masa Khalifah Abu Bakar ketika pasukan muslim memerangi orang-orang yang enggan mengeluarkan zakat (qiptal al-Murtaddin) banyak qurra' yang ikut perang gugur di medan pertempuran. Membiarkan hal ini jelas akan sangat berbahaya. Sebab hal ini akan sangat berpengaruh terhadap upaya memelihara keaslian dan keorisinilan al-Qur'an selaku kitab suci yang sedikitpun tidak boleh berubah. Dengan pertimbangan kemaslahatan terjadilah kodifikasi al-Qur'an yang pertama kali pada masa Khalifah Abu Bakar atas inisiatif sahabat agung genius Umar bin Khatab. Kondifikasi al-Qur'an mushaf semacam ini merupakan hal baru yang belum pernah terjadi pada masa Rasulullah Saw.

${ }^{25}$ Badran Abu al-'Ain Badran, Ushul al-Figh al-Islami (Iskandariyah: Mu'assasah Syabab al-Jami’ah, t.t), 472. 
Pada zaman Rasulullah, Abu Bakar, dan Umar bin Khattab apabila ada onta hilang, tidak boleh orang yang menemukan menangkapnya. Demikian hal itu dilakukan berdasarkan petunjuk hadis Nabi. Sebab onta itu kuat, tahan panas, tahan lapar dan haus. Tidak pula khawatir dimangsa binatang buas, karena ia dapat menyelamatkan diri dengan lari kencang.

Demikian juga tidak khawatir akan diambil oleh penjahat, karena waktu itu kondisi masyarakat cukup baik dan aman, belum banyak penjahat. Ketika Usman bin Affan (w. $35 \mathrm{H}$ ) menjadi khalifah, kondisinya sudah berubah. Masyarakat tidak aman lagi, sudah banyak penjahat yang suka mengambil hak milik orang lain. Oleh karena itu berdasarkan maslahat atau kemaslahatan, Khalifah Usman bin affan tidak menerapkan hadis Nabi tentang onta yang hilang itu secara harfiah.

Khalifah Usman mengambil keputusan bahwa siapa saja yang menemukan onta yang hilang hendaklah menangkapnya untuk kemudian menyerahkannya kepada khalifah. Bila pada batas waktu tertentu pemiliknya datang maka onta itu akan diserahkan kepada pemiliknya. Tetapi apabila dalam batas waktu tertentu pemilik tidak juga datang, maka onta itu dijual oleh khalifah dan hasil penjualannya diserahkan ke baitul mal (kas negara) untuk kepentingan kaum muslimin. Hal ini diambil oleh Usman berdasarkan kemaslahatan. Sebab jika tidak demikian, sesuai dengan kondisi masyarakat yang sudah tidak aman, onta itu akan hilang ditangan penjahat. ${ }^{26}$

Dari segi lahirnya, keputusan ini kontra atau berlawanan dengan hadis Nabi tentang onta yang hilang yang justru tidak boleh ditangkap itu. Tetapi hakikatnya keputusan ini semangat dan jiwanya justru sejalan dengan apa yang terkandung dalam hadis tersebut, yaitu bagaimana agar onta itu aman dan selamat. Dalam kondisi aman, itu akan pulang sendiri ke pemiliknya dengan selamat. Tidak khawatir 'digerayangi' oleh tangan jahil. Untuk itu maka onta itu tidak perlu ditangkap. Tetapi pada zaman Usman bin Affan, untuk mengamankan onta hilang itu justru harus ditangkap dan diserahkan kepada khalifah,agar tiddak diambil oleh penjahat. Itulah pertimbangan kemaslahatan.

${ }^{26}$ Yusif Musa, Tarikh al-Fiqh al-Islam, (t.tp.: Dar al-Ma'rifah, t.t), 8. 
Apa yang dilakukan oleh Usman bin affan tersebut sebagai contoh pembaruan hukum Islam dalam bentuk al-ijtihad fi tatbiq an-Nass (sebagaimana seharusnya kehendak nass itu diaplikasikan sesuai dengan fakta yang ada dilapangan). Jadi dalam kasus ini ketentuan hukunya sudah jelas. Ada nass-nya dalam bentuk hadis Nabi. Tetapi bagaimana seharusnya petunjuk hadis Nabi itu diterapkan setelah terjadi perubahan kondisi disituasi?

Disini bukan saja diperlukan keberanian untuk melakukan ijtihad, tetapi juga diperlukan kepiawaian berijtihad. Dan hal itu telah ditunjukkan oleh khalifah Usamn bin Affan.

Apa saja yang dilakukan oleh Usamn ini berbeda dengan yang dilakukan Abu Bakar Siddiq dalam masalah kondisikasi alQur'an. Kasus yang terjadi pada Abu Baka Siddiq, benar-benar merupakan kasus baru yang tidak ditemukan penegasannya dalam nass. Jadi memang belum tidak ada dalilnya, maslahahnya adalah secara harfiah hadis itu diterapkan justru tidak tepat. Tidak sejalan dengan tujuan umum pensyariatan hukum Islam, yaitu untuk mewujudkan kemaslahatan bagi umat manusia.

Ijtihad yang dilakukan Abu Bakar adalah ijtihad untuk menemukan hukum suatu masalah baru yang hukumnya belum atau tidak ditegaskan oleh nass (tidak ada atau belum ada dalil). Sedangkan ijtihad yang dilakukan oleh Usman bin Affan adalah ijtihad dalam bentuk bagaimana seharusnya kehendak nass itu diterapkan sesuai dengan fakta yang terjadi dilapangan. Yang pertama dikenal dengan "al-ijtihad fi-ma laisa lahu nassun sarih" ${ }^{27}$ dan yang kedua dikenal dengan "al-ijtihad fi tatbiq annass". ${ }^{28}$ Kedua-duanya merupakan suatu kebutuhan yang mesti dilakukan dalam rangka pembaruan hukum Islam.

Dengan mempelajari sejarah perkembangan huku Islam sejak dari masa sahabat, tabi'in, dan a'immahal-mujtahidin, kemudian menelah buku-buku fiqh karya mereka akan banyak sekali ditemukan hasil-hasil ijtihad dalam dua bentuk tersebut. Dan hal itu akan terus belanjut sampai hari ini. Bahan pada zaman di mana kehidupan telah begitu maju dengan pesatnya, dan begitu kompleks sebagai pengaruh kecangguhan teknologi dan globalisasi seperti dewasa ini, kebutuhan melakukan pembaruan hukum Islam dalam arti keberanian melakukan ijtihad dalam dua model tadi terasa sangat mendesak.

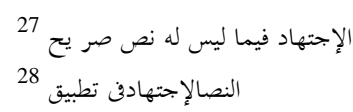


Dalam menghadapi kasus yang pernah dikaji oleh fuqaha terdahulu dan terjadi silang pendapat dikalangan mereka, dalam rangka pembaruan dapat melakukan ijtihad tarjih dengan membanding dan meseleksi pendapat-pendapat fuqaga' tersebut, mana diantara pendapat-pendapat itu yang paling kuat dalilnya atau yang lebih selesai dengan kemaslahatan dan tuntutan kemajuan zaman. Sebab, hasil ijtihad fuqaha' terdahulu yang terkondifikasikan dalam buku-buku fiqh dalam berbagai mazhab itu jumlahnya cukup banyak. Namun karena hal itu merupakan produk zamannya maka tidak semuanya masih cocok dan relevan untuk diterapkan pada saat kini. Disinilah perlunya ada ijtihad tarjih.

Dalam rangka pembaruan hukum Islam hal ini perlu dilakukan. Demikian agar umat Islam tidak terjebak pada pendapat yang sempit, atau lemah, yang ketinggalan zaman. Sebab kalau dikembali ke beberapa buku induk masing-masing mazhab yang berkembang dalam dunia Islam itu akan ditemukan adanya pandangan dan hasil ijtihad fuqaha' terdahulu yang masih sesuai dengan perkembangan kehidupan masa kini disamping adanya beberapa hasil ijtihad dan pandangan mereka yang memang mesti ditinggalkan karena sudah tidak relevan lagi dengan kondisi saat ini.

Untuk mengetahui hal itu tentu harus dilakukan penelitian yang mendalam dan ijtihad tarjih. Dengan cara ini hukum Islam akan tampil mempesona sesuai dengan tuntutan zaman. Perlu diketahui bahwa salah satu sebab kenapa kadang-kadang hukum Islam itu nampak kaku, jumud, dan ketinggalan zaman adalah karena umat Islam sering dengan hasil ijtihad ulama atau fiqh yang sempit, bahkan kadang-kadang lemah argumetasinya. Pada hal disisi lain ada pandangan yang lebih kuat dalilnya, yang lebih prospektif, dan lebih cocok dengan kamajuan zaman.

Melatih tidak semua permaslahan kehidupan ditemukan status hukumnya didalam al-Qur'an dan sunnah atau hadis, dan mengingat banyaknya maslah baru yang muncul yang belum pernah diijtihadkan oleh ulama-ulama terdahulu karena waktu itu memang belum muncul nampaknya ijtihad dalam rangka pembaruan hukum Islam bukan saja menjadi kebutuhan namun telah menjadi suatu keharusan. Ia telah menjadi sunnatullah yang tidak bisa dilepaskan dari jalannya roda kehidupan. 
Dalam kaitan ini Dr. Yusuf al-Qaradawi menyatakan sebagai berikut: "Dengan tetap menghormati dan menghargai hasil-hasil dan karya besar ulama-ulama terdahulu dibidang hukum Islam dewasa ini sangat memerlukan ijtihad untuk memecahkan masalah-masalah baru yang pada masa mereka memang belum pernah ada. Masing-masing masa mempunyai persoalan tersendiri yang tidak sama dengan masa yang lain. bahkan dimana dewasa ini berada jauh lebih memerlukan ijtihad jika dibanding dengan masa-masa yang lalu. Dihadapan telah terjadi gelombang perubahan yang luar biasa, sebagai akibat kemajuan dibidang industri dunia yang besar ini menjadi kecil." ${ }^{29}$

Kalau ulama-ulama dahulu berani menyatakan adanya prinsip "tagayyur al-fatwa bi-tagyyur az-zaman"30, fatwa itu bisa berubah sebab perubahan zaman, bagaimana harus hidup dizaman yang serba canggih ini? Jadi harus berani melangkah untuk melakukan perubahan.

\section{Mujtahid dan Lapangan Pembaruan Hukum Islam}

Setelah diketahui bahwa ijtihad dalam rangka pembaruan hukum Islam merupakan suatu keharusan dan kebutuhan agar setiap masalah kehidupan dapat diketahui status hukumnya, sehingga hukum Islam akan tetap eksis dengan segar dan dapat mengetahui siapakah yang berhak melakukan pembaruan hukum Islam itu dan dimana pembaruan hukum Islam tersebut harus dimainkan?

Paling tidak ada dua hal pokok yang harus diperhatikan agar ijtihad yang dilakukan dalam rangka pembaruan hukum Islam tersebut mendapatkan legitimasi dari para pakar hukum Islam dan mencapai sasaran. Dua hal pokok tersebut ialah ${ }^{31}$, yakni pertama, pelaku pembaruan hukum Islam itu adalah mereka yang memenuhi kualifikasi sebagai faqih atau mujtahid, kedua, pembaruan itu dilakukan diarea-tempat-tempat ijtihad atau majal al-ijtihad-yang dibenarkan.

${ }^{29}$ Yusuf al-Qardawi, al-Ijtihad al-Mu'asir (t.tp.: Dar at-Tauzi wa anNasyr al-Islamiyah, 1994), 5-6.

30 تغير الفتوى بتغيرمان

31 'Abd Wahhab Khallaf, Masadir at-Tasyri al-Islami fima la Nassa fih (Kuwait: Dar al-Qalam, t.t), 8-17, Badran Abu al-'Ain Badran, Ushul al-Fiqh al-Islami (Iskandariyah: Mu'assasah Syabab al-Jami’ah, t.t), 471-476. 
Beberapa persyaratan yang harus dipenuhi oleh seseorang yang ingin melakukan ijtihad menurut para hukum Islam (fuqaha atau usuliyyun) dapat disimpulkan sebagai berikut:

Pertama, menguasai bahas Arab. Al-Qur'an dan asSunnah atau hadis selaku sumber atau dall pokok hukum Islam ditulis dengan bahasa Arab. Untuk itu seseorang yang ingin melakukan ijtihad harus menguasai bahasa Arab, agar mampu memahami nass atau dalil demi dalil yang dianalisisnya secara baik dan benar. ${ }^{32}$ Dengan demikian pembaruan hukum Islam yang dilakukan oleh mereka yang tidak memahi bahasa Arab, pada hakikatnya bukanlah pembaruan.

Kedua, mengetahui hukum-hukum Allah yang ada didalam al-Qur'an. Maksudnya ia harus menguasai ayat-ayat ahkam. Ia mampu mengadirkan setiap diperlukan, mampu menganalisisnya, untuk kemudian melakukan istinbat dari tersebut sesuai dengan maslah yang dihadapi yang perlu didudukan hukumnya. ${ }^{33}$ Dalam hal ini berarti ia harus memahami nasikh mansukh dan asbab an-nuzul.

Ketiga, mengetahui hukum-hukum Allah yang ada di dalam as-Sunnah atau hadis. Artinya ia harus menguasai hadis ahkam, sebagai mudah bagiannya setiap diperlukan untuk menghindarkannya, melakukan analisis, kemudian mengambil kesimpulan hukum sehubungan dengan kasus yang tengah dihadapinya. ${ }^{34}$ Untuk ini ia tentu harus memahami ilmu hadis.

Keempat, menguasai hukum-hukum Islam yang di-ijma'kan oleh fuqaha', sehingga ia tidak berijtihad yang hasilnya kontra dengan ijma', ${ }^{35}$

${ }^{32}$ Al-Asnawi, Nihayah al-Wusul (Beirut : Alam al-Kutub, 1982), 551552.

${ }^{33}$ Asy-Syafi'i, ar-Risalah, cet. Ke-1 (Kairo: Matba'ah al-Halabi, t.t.), 510.

${ }^{34}$ Al-Ghazali, al-Mustasfa min 'Ilm usul, juz.2 (t.tp.: Dar al-Fikr, t.t), 103.

35 Asy-Syaukani, Irsyad al-Fukhul (Surabaya: Salim bin Sa'id, t. t), 251. 
Kelima, menguasai kaidah-kaidah ushul al-fiqh, yang tiada lain berupa kaidah-kaidah istinbat atau ijtihad yang dapat dijadikan alat untuk melakukan istinbat hukum baik dalam kondisi ditemukan nass maupun dalam kondisi tidak ada nass atau tidak ditemukan dalilnya didalam al-Qur'an maupun asSunnah atau hadis. ${ }^{36}$ Imam Fakhr ar-Razi menyatakan ilmu yang paling penting yang harus dikuasi oleh mujtahid adalah usul alfigh. ${ }^{37}$ Sementara itu al-Ghazali menyatakan, ilmu ijtihad yang paling penting ada tiga, ilmu hadis, bahasa dan usul al-figh.

Keenam, memahami maqasid asy-Syari'ah. ${ }^{38}$ Ini merupakan hal yang amat penting. Sebab kemampuan mujtahid memahami nass dan menerapkannya pada kasus yang dihadapi sangat tergantung kepada kemampuan mujtahid tersebut memahami maqasid asyri'ah (tujuan umum pensyariatan hukum Islam), yang dimaksud untuk mewujudkan kemaslahatan manusia, yaitu agama, akal, jiwa, harta, dan keturunan atau kehormatan. Di sinilah metode qiyas, istilah, istihsan, dan isad al-zari'ah akan memainkan peranannya.

Itulah persyaratan pokok yang harus dimiliki mujtahid agar ia mampu melakukan pembaruah hukum Islam. Dengan demikian pembaruan hukum Islam yang dilakukan oleh mereka yang tidak memenuhi kriteria tersebut tidaklah dapat dinamakan sebagai pembaruan. Ia lebih tepat dikatakan sebagai penghancuran hukum Islam.

Itulah sebabnya kenapa ketika dipenghujung pertengahan abad ke-VI Hijriyah terjadi kekacauan dalam berijtihad, dimana ijtihad dilakukan oleh yang bukan ahlinya, para ulama yang ada pada waktu dimaksudkan agar terjadi kekacauan dalam hukum Islam. Hanya saja antisipasi ini tidak tepat. Sebab ibarat mengobati penyakit dengan penyakit. Hal ini berdampak negative terhadap perkembangan hukum Islam yang pengaruhnya sangat dirasakan sampai hari ini.

${ }^{36}$ Zaki ad-Din Sya'ban, Ushul al-Fiqh, cet. Ke-1 (t.tp: Matba'ah Dar atTa'lif, t.t), 326 .

${ }^{37}$ Fakhr ad-Din ar-Razi, al-Mahsul fi 'Ilm Usul al-Fiqh, cek ke-1, jilid.2 (Beirut: Dar al-Kutub al-Ilmiyah, 1998), 499.

${ }^{38}$ Sy-Syatibi, al-Muwafaqat, juz.4 (t.tp.: Dar al-Fikr, t.t), 105-106. 
Oleh karena pintu ijtihad dinyatakan telah ditutup maka tidak ada yang berani lagi memasukinya. Dengan tidak ada yang berani lagi memasuki pintu ijtihad, dunia Islam diselimuti oleh kabut gelap kejumudan, kebekuan, dan secara perlahan tapi sinar hukum Islam mulai pudar. Taqlid buta dan ta'asub mazhab akhirnya mencengkeram umat Islam. Bukan saja dikalangan awam, bahkan ulama dan kyainya-pun ikut-ikutan terkena wabah yang tidak sehat itu. Dalam kondisi seperti ini tentu hukum Islam ketinggalan zaman. Pada hal pintu ijtihad ditutup itu maksudnya bagi mereka yang tidak memenuhi persyaratan ijtihad. Bagi yang mampu melakukan lantaran memenuhi persyaratan semestinya harus berani tampil kedepan.

Sesuai dengan pesatnya perkembangan ilmu pengetahuan dan kompleksitas kehidupan yang dihadapi umat manusia diabad modern ini, persyaratan ijtihad di atas belum memadai, perlu ditambah dengan ilmu-ilmu bantu sesuai dengan kasus dan obyek yang dihadapi. Dalam menyelesaikan masalah-masalah sosial kemasyarakatan misalnya seorang mujtihad yang ingin melakukan pembaruan hukum Islam memahami sosiologi, antropologi, ilmu jiwa sosial, patologi sosial, dan lain sebagainya.

Dalam menghadap masalah ekonomi misalnya, ia pun harus dibekali dengan ilmu yang berhubungan dengan selukbeluk perkonomian. Dalam menyelesaikan hal-hal yang berkaitan dengan politik dan kebijakan penguasa, mujtihad perlu membekali dirinya dengan ilmu yang berhubungan dengan ingin melakukan ijtihad dalam masalah yang berhubungan dengan kesehatan, ia harus mempunyai bekal ilmu yang berhubungan dengan hal tersebut. Begitulah seterusnya. Dengan cara ini hasil ijtihad yang dilakukannya diharapkan lebih mendekati kepada kebenaran.

Kalau persyaratan yang cukup banyak itu tidak dapat dimiliki oleh seseorang ada dua cara yang dapat dilakukan. Pertama persyaratan itu dipadatkan atau disederhanakan. Seseorang cukup menguasai ayat dan hadis tertentu yang dijadikan obyek ijtihad. Hal-hal lain yang berkaitan dengan itu lebih jauh dapat bertanya kepada para ahlinya. Misalnya apakah ayat itu mansukh atau tidak bisa bertanya kepada ahli tafsir. Atau apakah hadis itu sahih atau tidak dapat bertanya kepada ahli hadis. Demikian juga ilmu-ilmu bantu lain yang sifatnya umum tadi, tidak mesti menguasai sendiri. Tetapi cukup bertanya kepada alinya masing-masing. 
Misalnya bila yang menjadi obyek penelitiannya itu berkaitan dengan ilmu kedokteran, ia bisa bertanya kepada dokter ahli, dan seterusnya. Hanya saja, karena ilmu-ilmu itu tidak dikuasinya sendiri tentu agak merepotkan. Sebab setiap ia akan berijtihad harus bertanya kesana kemari.

Imam asy-Syatibi menyatakan bahwa ijtihad itu dapat dilakukan oleh seseorang yang menguasai dua hal. Pertama mampu memahami maqasid asy-syari'ah (tujuan pensyari'atan hukum Islam) secara sempurna. Kedua ia mampu melakukan istinbat hukum berdasarkan pemahamannya terhadap maqasid asy-syari'ah tersebut. Dalam bagian lain ia menyatakan bahwa mujtihad tidak mesti menguasai semua ilmu yang diperlukan dalam berijtihad dan mempercayakan kepada para ahlinya. Ilmu nasikh-mansukh misalnya dapat bertanya kepada yang ahli dibidang ini. Mengenai sahih dan tidaknya hadis dapat berpedoman dengan penilaian para ahlinya. Tentang qira' at, mujtihad dapat bertanya dan mempercayakan kepada ahlinya. ${ }^{39}$

Dalam artikel ini apa yang disampaikan asy-Syatibi tersebut merupakan syarat ijtihad yang dipadatkan atau disederhanakan. Sebab yang tidak memahami bahasa Arab dengan baik akan sanggup memahami maqasid asy-syari'ah pada dalil yang sedang menjadi obyek ijtihadnya. Demikian juga seseorang yang tidak memahami kaidah-kaidah usul al-fiqh. Mampukah dia melakukan istinbat hukum Islam? Untuk itu persyaratan penguasa bahasa Arab dan kaidah-kaidah istinbat itu mutlak diperlukan.

Memang, usuliyyun berbeda pendapat tentang persyaratan ijtihad tersebut. Tetapi mayoritas buku-buku usulal-fiqh baik karya ulama-ulama terdahulu maupunn buah tangan ulama-ulama masa kini semuanya mecantumkan minimal 6 persyaratan di atas. Bahkan banyak yang mencantumkan lebih dari itu.

Hanya Imam asy-Syatibi yang menyatakan cukup diperlukan dua persyaratan untuk melakukann ijtihad, yaitu mampu memahami maqasid asy-Syari'ah dengan sempurna dan mampu melakukan istinbat hukum Islam sesuai dengan pemahamannya terhadap maqasid asy-Syari'ah. Namun, dua syarat itu adalah syarat pokok yag dipadatkan.

${ }^{39}$ Sy-Syatibi, al-Muwafaqat, juz.4 (t.tp.: Dar al-Fikr, t.t), 105-106. 
Kemudian dimana dan dalam hal apa saja mujtihad itu dapat melakukan ijtihad dalam rangka pembaruan huku Islam? Usuliyyun telah menetapkan bahwa ijtihad itu harus dilakukan pada lapangan atau tempat-tempat yang dibenarkan padanya dilakukan ijtihad ( $f i$ majal al-ijtihad). Untuk itu bagi seseorang yang ingin melakukan pembaruan terlebih dahulu adakah masalah yang ingin di-ijtihad-kan itu termasuk kawasan yang dibenarkan untuk dilakukan ijtihad ataukah termasuk kawasan yang dibenarkan untuk dilakukan ijtihad ataukah termasuk kawasan yang tidak dibenarkan untuk dilakukan ijtihad? Apabila masalah yang ingin di-ijtihad-kan itu termasuk kawasan yang dibenarkan dilakukan ijtihad ia perlu maju. Dan apabila kebalikannya maka ia harus mundur dan mencari lapangan lain yang dibenarkan.

Beberapa tempat yang padanya dapat dilakukan ijtihad dalam rangka pembaruan hukum Islam dapat disimpulkan sebagai berikut: ${ }^{40}$

Pertama, setiap kasus baru yang tidak ada penegasan hukumnya dalam nass al-Qur'an atau as-Sunnah (hadis) dan belum pernah dibahas oleh fuqaha' dan para imam mujthaid terdahulu. Masalah transplantasi organ tubuh manusia, penggantian katub jantung manusia dengan katub jantung babi, bank sperma, ATM semuanya termasuk kelompok ini.

Kedua, kasus baru yang tidak ada penegasan hukumnya dalam nass al-Qur'an atau as-Sunnah (hadis) dan sudah dikaji oleh ijtihad ulama-ulama terdahulu, tetapi masih terjadi silang pendapat dan belum membawa hasil yang memuaskan.

Ketiga, beberapa dalil yang statusnya zann ad-dilalah baik didalam al-Qur'an maupun as-Sunnah (hadis), yaitu beberapa dalil yang mengandung makna keboleh jadian atau ihtimalat yang terbuka lebar untuk menerima penakwilan dan penafsiran. Adanya ijtihad dalam bentuk penafsiran ulang untuk mendapatkan produk hukum yang lebih relevan dengan kemajuan zaman pada dalil-dalil semacam ini sangat memungkinkan dan terbuka lebar.

40 'Abd Wahhab Khallaf, Masadir at-Tasyri al-Islami fima la Nassa fih (Kuwait: Dar al-Qalam, t.t), 8-10. Badran Abu al-'Ain Badran, Ushul al-Fiqh al-Islami (Iskandariyah: Mu'assasah Syabab al-Jami’ah, t.t), 472-474. 
Keempat,_beberapa nass baik di dalam al-Qur'an maupun as-Sunnah (hadis) yang ma'qulah al-ma'na (dapat difilsafatkan atau dirasionalisasikan). Nass itu secara tegas telah menunjukan ketetapan hukum tertentu. Tetapi ketika hal itu akan diaplikasikan ketetapan hukum tertentu. Tetapi ketika hal itu akan diaplikasikan dilapangan ternyata fakta di lapangan sudah berubah atau tidak mendukung lagi, sehingga apabila terpaksa dilakukan secara tekstual seperti yang ada pada nass itu tidak sejalan dengan maqasid asy-syari'ah. Inilah yang dikenal dengan istilah alijtihad fi tatbiq an-nass. ${ }^{41}$ Tindakan Khalifah Umar bin Khattab tidak memberikan bagian zakat kepada muallaf termasuk contoh ini.

Kelima, hukum Islam yang bersifat ta'aqquli, yaitu hukum Islam yang kausalitas hukumnya dapat diketahui oleh mujtahi baik yang mansusah maupun yang mustanbatah. Pendapat yang membenarkan pemberian zakat dalam bentuk qimah (nilai), Abu Hanifah termasuk kategori ini.

Keenam, hasil-hasil ijtihad ulama terdahulu yang masih diperselisihkan ijtihad dibidang ini bisa dilakukan dalam bentuk benar-benar memunculkan pendapat baru yang lebih orisinal dan menjaman. Atau dengan menyeleksi dan men-tarjih pendapatpendapat tersebut untuk memiliki mana yang paling kuat dalilnya dan paling sesuai dengan kemaslahatan.

Imam al-Fakhr ar-Razi menyatakan bahwa kasus yang boleh dilakukan ijtihad padanya ialah setiap hukum Islam yang tidak ditegaskan oleh dalil qat'i. Masalah-masalah aqidah dan hukum Islam yang ditunjukkan dalil qat' $i$ seperti wajibnya salat lima waktu, zakat dan masalah-masalah yang hukumnya telah diijma'-kan oleh ulama tidak dapat dilakukan ijtihad. ${ }^{42} \mathrm{Abu}$ alHusain al-Basri menyatakan bahwa masalah-masalah yang boleh dilakukan ijtihad ialah masalah-masalah yang hukumnya diperselisihkan oleh para mujtahid. ${ }^{43}$

الإجتهاد في تطبيق النص 41

${ }^{42}$ Fakhr ad-Din ar-Razi, al-Mahsul fi 'Ilm Usul al-Fiqh, cek ke-1, juz.2 (Beirut: Dar al-Kutub al-Ilmiyah, 1998), 39.

${ }^{43}$ Fakhr ad-Din ar-Razi, al-Mahsul fi 'Ilm Usul al-Fiqh, cek ke-1, juz.2 (Beirut: Dar al-Kutub al-Ilmiyah, 1998), 39. 
Al-Hudari menyebutkan bahwa kasus yang paling dilakukan ijtihad ialah setiap hukum Islam yang dalilnya tidak bersifat qat'i. Sedangkan hukum Islam yang diketahui secara jelas dari agama (ma'ulima min ad-din bi ad-darurah) ${ }^{44}$ yang telah disepakati oleh fuqaha' tidak dapat dilakukan ijtihad.

Seperti kewajiban salat lima waktu, zakat, dan lain-lain. lebih lanjut ia menyatakan bahwa selama ijtihad itu dilakukan oleh ahlinya (memenuhi persyaratan) dan dilakukan pada tempatnya maka hasil ijtihad itu mengikat pelakunya dan boleh difatwakan untuk yang lain. ${ }^{45}$

Imam Al-Amidi menegaskan bahwa hal-hal yang boleh dilakukan ijtihad beberapa hukum Islam yang dalilnya zanni. Hukum Islam bukanlah kawasan yang dapat dilakukan ijtihad. Sebab ijtihad yang salah dalam kasus seperti itu anggap berdosa. Sedangka masalah yang boleh dilakukan ijtihad adalah masalah dimana siapa yang salah dalam berijtihad padanya tidak dipandang berdosa. ${ }^{46}$ Dr. Adib as-Sahih menyatakan bahwa halhal yang boleh dilakukan ijtihad ialah hal-hal yang belum ada penegasan hukumnya yang jelas oleh nass.

Lapangan ijtihad terbentang luas, bisa dilakukan pada masalah-masalah baru yang tidak ditunjukan oleh nass hukumnya. Hal itu dapat dilakukan lewat metode qiyas, istislah, dan lain-lain. ${ }^{47}$ Al-Ghazali menyatakan bahwa yang boleh dilakukan ijtihad ialah setiap hukum Islam yang tidak berdasarkan dalil qat'i $i^{48}$

Sementara itu Al-Kalbi (Abu al-Qasim Muhammad bin Ahmad bin Jazi al-Maliki) menyatakan bahwa hukum Islam itu terbagi menjadi tiga.

Pertama, tidak boleh dilakuakan ijtihad, karena hal itu sudah diketahui secara jelas dari ajaran agama Islam, seperti salat lima waktu, puasa Ramadhan, dan haramnya khamar. Siapa yang menyalahinya berdosa berdasarkan ijma' dan dihukumi kufur. Sebab ijtihad yang menyalahinya dipandang mendustakan Allah dan Rasul-Nya.

معلم من الدين بالضرورة 44

45 Al-Hudari, Usul al-Fiqh, cet. Ke-7 (t.tp.: Dar al-Fikr, 1981), 370.

${ }^{46}$ Al-Amidi, al-Ihkam fi usul al-Ahkam, juz.4 (Beirut: Dar al-Kutub al'Ilmiyah, t.t), 164.

${ }^{47}$ Adib as-Salih, Tafsir an-Nusus, juz.1 (Beirut: Dar al-Jil, t.t), 80.

48 Al-Ghazali, al-Mustasfa min 'Ilm usul, juz.2 (t.tp.: Dar al-Fikr, t.t), 103. 
Kedua, hukum Islam yang tidak diketahui secara jelas tersebut. Seperti kewajiban maskawin dalam nikah, haramnya menikahi kembali mantan isteri yang ditalak tiga kecuali setelah menikah lagi, terjadi hubungan suami isteri dan dicerai oleh suaminya yang kedua. Hal seperti ini tidak boleh diijtihadkan kembali. Barang siapa melakukanya dan menyalahi maka berdasarkan ijma' ia dihukumi dosa dan fasiq.

Dan ketiga, hukum Islam yang padanya boleh dilakukan ijtihad, yaitu setiap hukum Islam yang diperselisihkan oleh ulama. $^{49}$

Dari beberapa pandangan di atas dapat diambil kesimpulan bahwa kawasan atau lapangan hukum Islam yang tidak bisa dimasuki ijtihad ialah :

Pertama, hukum Islam yang telah ditegaskan oleh nass sahih yang berstatus qat'i yang tidak menerima penafsiran atau pentawilan lagi. Bagain waris anak perempuan yang mendapat satu dibanding dua anak laki-laki termasuk kategori ini. Oleh karena itu tidak dibenarkan dengan pertimbangan maslahat dan atas nama pembaruan hal tersebut diijtihadi untuk diubah. Dalam hal ini berlaku kaidah la ijtihada fi muqabala an-nass,${ }^{50}$ ijtihad itu tidak dapat dibenarkan atau gugur bila berhadapan dengan nass.

Kedua, beberapa dalil yang statusnya qat'i ad-dalalah. Kalau pada nomor satu tekanannya pada produk hukumnya, maka pada nomor dua ini tekanannya pada dalilnya atau nass-nya. Nass semacam ini tidak dapat dilakukan padanya ijtihad dalam arti alijtihad fi figh an-nass atau istinbat al-hakam ${ }^{51}$ (menggali hukum yang ditunjukkannya). Tetapi bisa dilakukan ijtihad dengan pengertian al-ijtah fi tatbiq an-nass (bagaimana seharusnya produk hukum yang ditunjukkan oleh nas itu diterapkan dilapangan). Inilah yang dalam ushul al-fiqh dikenal dnegan tahqiq al-mannat ${ }^{52}$. Tindakan khalifah usman tentang onta hilang harus ditangkap dan diserahkan kepada khalifah termasuk kategori ini.

${ }^{49}$ Al-Kalbi, Taqrib al-Wusul ila 'Ilm al-Ushul, Tahqiq Dr. AsySyanqiti, (Cairo : Maktabah Ibn Taymiyah, 1414 H), 439-441.

\footnotetext{
لا اجتهاد في مقابلة الناس 50

الاجتهاد في فقه النص أو استباط الأحكام الشرة 51

تحقيق المناط 52
} 
Ketiga, hukum Islam yang diketahu secara jelas dari ajran agam Islam (ma ulima min ad-din bi ad-darurah) ${ }^{53}$, seperti kewajiban shalat lima waktu, puasa ramadhan, zakat, ibdah haji, birul walidain, keharaman mencuri, zinnah, minum-minuman keras, riba, dan lail-lain. kesemuanya ini tidak dapat dilakukan ijtihad untuk mengubah status hukum masing-masing.

Keempat, hukum Islam yang bersifat ta'abudi (hukum islam yang kausalitas atau illat hukumnya tidak dapat dideteksi oleh mujtahdi) diaman hanya Allah yang mengetahuinya. Misalnya kurban atau aqiqah mesti dilakukan dalam bentuk menyembeli binantang ternak. Dalam hal ini seperti ini tidak dapat dilakukan ijitihad untuk mengubah pelaksanaan aqiqah atau kurban dalam bentuk lain, misalnya diganti dengan uang.

Kelima, hukum Islam yang telah terjadi ijma' atau consensus dikalangan ulama yang diketahui secara jesal dari ajaran agama Islam, menurut sebagian ulama. Sebagian yang lain menyatakan, kalau yang diijma'kan itu merupakan (ma ulima min ad-din bi ad-darurah) $)^{54}$, maka sudah termasuk nomor tiga. dan jika yang diijma'kan itu berupa masalah ijtihadiah maka bisa dilakukan ijtihad baru. Namun dicatat untuk terjadi ijma' "dalam kasus kedua amat sulit. Untuk itu pembaruan hukum Islam yang dilakukan oleh yang bukan ahlinya atau dilakukan oleh ahlinya tetapi tidak dalam kawasan yang dibenarkan secara tegas dapat dikatakan bukan pembaruan hukum Islam. Hal seperti itu justeru akan memporak-prarandakan bangunan hukum Islam.

\footnotetext{
ما علم من الدين بالضرورة 53

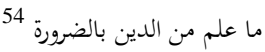




\section{Reorientasi Maslahah Mursalah Al-Ghazali dengan Upaya Pembaruan Hukum Islam}

Kata relevansi berarti dari bahasa inggris relevance yang secara etimologis berarti "keperluan, hubungan, penelitian, sangkut paut". 55 Didalam bahasa Indonesia, kata relevansi mengandung arti "hubungan atau kaitan". Sedangkan relevan berarti "kaitan mengait, bersangkut paut, berguna secara langsung". ${ }^{56}$ Yang dimaksud dengan relevansi dalam artikel ini ialah hubungan dan kegunaan secara langsung pemikiran alGhazali tentang maslahah mursalah dengan upaya pembaruan hukum Islam.

Di atas telah dijelaskan bahwa yang dimaksud dengan pembaruan hukum Islam dalam kajian ini adalah pembaruan yang dilakukan melalui ijtihad sebagaimana kriteria dan aturan yang dilakukan melalui ijtihad sebagaimana kriteria dan aturannya telah disebutkan.

Pelaku pembaruan itu mesti mereka yang memiliki kualifikasi mujtahid, dan ijtihad yang dilakukannya dalam rangka pembaruan tersebut mesti dilakukan sesuai dengan aturan yang telah digariskan, yaitu di tempat-tempat atau kawasan yang padanya dibenarkan untuk dilakukan ijtihad. Dalam berijtihad banyak metodologi yang dapat dilakukan. Bisa melalui qiyas, istihsan, sad az-zari'ah dan sebagaimananya. Hal ini tergantung kondisinya, mana menurut analisis matang mujtahid yang paling tepat dipakai dalam memecahkan persoalan hukum yang dihadapi itu.

Dalam menghadapi kasus baru yang belum ada penegasannya dalam nass (teks) al-Qur'an dan as-Sunnah (hadis), khususnya masalah-masalah kemasyarakatan yang banyak menyangkut kepentingan umum, kalau dimenengok kembali ihwal ijtihad yang banyak dilakukan oleh para sahabat, tab 'in dan al-a'immah al-mujtahidun rasanya tidak berlebihan kalau dikatakan bahwa diantara sekian metode terdebut, metode istislah nampaknya yang paling dominan.

${ }^{55}$ John M. Echols dan Hasan Shadly, Kamus Inggris Indonesia (Jakarta : PT Gramedia Pustaka Utama, 1978), 475.

${ }^{56}$ Depdikbud, Kamus Besar Bahasa Indonesia, cet. Ke-7, edisi ke-2 (Jakarta : Balai Pustaka, 1996), 830. 
Demikian juga perkembangan yang tengah terjadi dikalangan pakar hukum Islam, nampaknya dalam upaya memecahkan masalah-masalah baru yang terjadi ditengah-tengah masyarakat ada trend baru, dimana mereka cenderung melakukannya lewat pendekatan maqasid asy-syari'ah, bukan pendekatan kebahasaan.

Hal ini artinya mereka lebih banyak mempergunakan metode istislah dari pada yang lain, kenapa hal ini terjadi? hal ini terjadi karena dua alasan, pertama, pengembangan hukum Islam lewat pendekatan maqasid tidak memerlukan penguasaan bahasa Arab yang maksimal sebagaimana apabila hal itu dilakukan pendekatan kebahasaan. Jadi salah satu syarat ijtihad dalam bentuk penguasaan bahasa Arab disini bisa diminimalkan, kedua (ini yang lebih dominan), kasus baru belum pernah terjadi pada saat wahyu masih turun.

Wahyu sama sekali dicari persamaanya dalam al-Qur'an atau as-Sunnah (hadis). Atau dengan bahasa yang sejalan dengan topi yang diteliti ini (maslahah mursalah), maslahat atau kemaslahatan yang ditemukan dilapangan yang belum pernah terjadi pada saat wahyu masih turun. Wahyu sama sekali tidak menyinggungnya, sehingga model dan tipologinya tidak bisa dicari persamaannya dalam al-Qur'an atau as-Sunnah (hadis).

Atau dengan bahasa yang sejalan dengan topik yang diteliti ini (maslahah mursalah), maslahat atau kemaslahatan yang ditemukan dilapangan yang sejalan dengan jenis tindakan syara' atau penetapan hukum Islam (mulaimah li-jinsi tasarrufat asy-syar'iyyah ${ }^{57}$, itu tidak ada dalil khusus atau tertentu yang menunjukannya.

Pemecahan kasus semacam ini, tentu tidak dapat ditempuh melalui metode qiyas. Juga tidak bisa dengan metodemetode yang lain. Metode yang pas dan tepat yang harus dipergunakan untuk memecahkan masalah semacam itu adalah istilah. Al-Ghazali mempunyai pandangan yang cukup mendalam tentang maslahah mursalah. Ia telah membalasnya secara detail berikut percontohan-percontohannya.

اشر عية ملائمة للجنس تصرفات 57 
Mana yang dapat dibenarkan mana yang tidak. Mana yang masih bisa ditolerir dan mana yang harus ditolak. Mana yang disepakati dan mana yang diperselisihkan.

Dengan metode istislah, telah berusaha mengajar bagaimana seharusnya metode itu dipergunakan pada saat menghadapi persoalan kehidupan. Nampaknya ia sangat mumpuni dibidang ini. Selaku tokoh usuliyyin mazhab Syafi'i tidak berlebihan kalau di katakan tidak ada duanya.

Al-Ghazali mempergunakan istislah sebagia metode istinbat hukum Islam dan menjadikan maslahah mursalah sebagai indikasi positif pertimbangan penetapan hukum Islam, merupakan tokoh modern (tawassut). Tidak kaku seperti mereka yang sama sekali menolaknya, tidak begitu sering sebagaimana kalang Maliki, tidak pula begitu berani seperti at-Tufi, ini sangat menarik.

Untuk itu dalam rangka pembaruan hukum Islam, pandangan al-Ghazali tentang maslahah mursalah inilah yang banyak dapat menyelesaikan persoalan hukum Islam akan dihadapi masyarakat. Sebab dalam kondisi banyak masalah baru yang muncul yang perlu segera diselesaikan, umat akan banyak mengalami kesulitan kalau mengikuti pandangan yang tidak membenarkan maslahah mursalah dijadikan dalil untuk mengambil pertimbangan dalam menetapkan hukum Islam. Apabila pandangan ini yang diikuti maka akan banyak ditemukan adanya masalah baru yang tidak dapat didudukkan status hukumnya sepanjang kajian hukum Islam. Dengan cara ini jelas Islam akan ketinggalan zaman.

Demikian juga apabila mengikuti pandangan yang terlalu maju sebagaimana diwakilkan oleh at-Tufi, atau dalam menentukan maslahat atau kemaslahatan itu terlalu bebas, tidak terkait dengan aturan-aturan yang mengendalikannya. Hal semacam ini bisa berpengaruh negatif, bahkan membahayakan dan mengancam eksistensi hukum Islam.

Sebab pendapat semacam ini akan menumbuh suburkan pembaru-pembaru yang dengan dalih pembaruan dan atas nama kemaslahatan berani merobak hukum-hukum Islam yang sudah pasti yang tidak mungkin diubah lagi. Atau dengan dalih pembaruan dan kemajuan berani melanggar nass qat'i yang sarih (teks hukum dalam al-Qur'an atau as-Sunnah dan hadis yang pengertiannya betsifat pasti yang tegas dan jelas). 
Memberikan hal ini jelas akan berbahaya. Bukan saja akan mengancam eksistensi hukum Islam, tetapi juga akan menimbulkan kekacauan dibidang hukum.

Maslahah mursalah perlu digalakan, tetapi untuk kehatihatian, perlu mengambil jalan tengah, yaitu pandangan alGhazali. Kenapa maslahah mursalah harus digalakan? Sebab tujuan inti penyariatan hukum Islam adalah untuk mewujudkan kemaslahatan (jalbi maslih al-Ibad) ${ }^{58}$, baik didunia maupun di akhirat. Inilah karakter yang paling menonjol yang melekat pada hukum Islam.

Dari prinsip dasar bahwa tujuan umum penyariatan hukum islam adalah untuk mewujudkan kemaslahatan inilah maka muncul beberapa metodologi ijtihad atau istinbad yang kesemuanya mengfacu dan bertumpu kepada kemaslahatan, seperti qiyas, istislah, istihan, sad az-zari'ah, dan istishab.

Sebagaimana halnya pensyari'atan hukum Islam tidak bisa dipisahkan dari kemaslahatan, demikin juga masalah kehidupan umat manusia di dunia ini tidak mungkin terlepaskan dari kemaslahatan tersebut. Kemaslahatan umat manusia tidak sama dan banyak ragam serta variasinya, disamping itu kemaslahatan umat selalu berkembang dan berbuah-buah sesuai dengan kemajuan zaman.

Untuk itu perlu ada ukuran, batasan, dan kreteria dan hukum Islam harus sanggup menjawabnya. Jawaban itu antara lain dapat diberikan dengan menjadikan maslahah mursalah sebagai dalil atu pertimbangan dalam menjadikan istislah sebagai metode istinbat hukum Islam sebagaimana seluk-seluk dan ihwalnya telah dipaparkan al-Ghazali.

Berdasarkan pertimbangan maslahah mursalah, banyak permasalahan baru yang hukumnya belum menjelaskan al-Qur'an dan as-Sunnah serta belum terpecahkan oleh dalil-dalil yang lain, akan dapat diketahui hukumnya.

جلب المصالح العباد 58 
Sebagai contoh misalnya berdasarkan maslahah mursalah pemerintah dapat menetapkan mata uang, pajak harta, restribusi perpakiran, harga resmi, pendistribusian sembako, pemberian kredit kepada usaha kecil, pemotongan gaji pegawai negeri untuk mengatasi krisis moneter, penghapus SPP, pengaturan letak bangunan tempat-tempat ibadah, mencopot penjabat yang berbau Korupsi Kolusi dan Nepotisme (KKN) yang menyalahi prinsip ahliyah (tidak professional), mengatur bahkan melarang mahasiswa untuk berdemontrasi, membuat undang-undang kepartaian, membatasi pendirian partai, membuat undang-undang pemilu, membatasi kekuasaan presiden, likuidasi bank bermasalah, rekapitalisasi bank, kode etik jurnalistik, aturan berkampanye, sanksi berat bagi penjabat yang ber-KKN, pengaturan pendirian rumah ibadat, pasar, tempat-tempat hiburan, lapangan golf, perumahan, daerah-daerah industri, pertanian, pendirian yayasan dan lembaga-lembaga pendidikan dan lainlain, mengatur hari dan jam kerja, dan masih banyak lagi.

Tegasan dengan menggalakan metode istislah akan banyak masalah baru yang dapat dipecahkan. Dngan banyak masalah baru yang dapat muncul produk hukum yang baru. Dengan banyak produk hukum Islam baru yang dapat dimasyarakatkan hukum Islam akan tetap eksis. Dan dengan adanya jawaban Islam terhadap setiap kasus baru yang muncul, hukum Islam akan selalu up to date, sesuai dan mengikuti perkembangan zaman. Dan dengan demikian, tujuan pokok hukum Islam yang dimaksudkan untuk mewujudkan kemaslahatan bagi umat sejalan dengan misi Islam yang "rahmatan lil- 'alamin" akan dapat diwujudkan 


\section{E. Penutup}

Kesimpulan dalam arikel ini adalah maslahah mursalah atau istislah menurut al-Ghazali dapat dijadikan dalil (hujjah) penetapan hukum Islam dengan ketentuan:

1) Maslahat itu sejalan dengan tindakan syara', mula'imah litasarufat asy-syar, 59

2) Tidak berlawanan dengan al-Qur'an, as-Sunnah ataupun ijma'

3) Menempati level daruriyat atau hajiyat yang setingkat dengan daruriyat

4) Berstatus qat'i atau zann yang mendekati qat' $i$

5) Dalam kasus tertentu diperlukan persyaratan qat'iyah, daruriyat, dan kulliyat, seperti kasus tawanan muslim yang dijadikan perisai oleh musuh dan sejenisnya.

Ketentuan 1 dan 2 sama dengan asy-Syatibi, selebihnya tidak. Bagi at-Tufi, karena tidak mengenal istilah maslahah mursalah, otomatis tidak ada persyaratan sebagaimana diungkapkan al-Ghazali. Maslahah mursalah menurut al-Ghazali tidak merupakan dalil yang berdiri sendiri yang terlepas dari alQur'an, as-Sunnah, ijma'. Dengan demikian, bagi al-Ghazali istislah lebih tetap dipandang sebagai metode istinbath hukum Islam, bukan dalil sumber hukum Islam.

Di sini al-Ghazali berbeda dengan asy-Syatibi dan at-Tufi. Asy-Syatibi sebagai tokoh ushuliyyin yang mewakili mazhab Maliki memandang maslahah mursalah sebagai dalil yang berdiri sendiri. sementara itu, menurut at-Tufi dari mazhab Hanbali, maslahat (bukan maslahah mursalah) dipandang sebagai dalil hukum Islam yang berdiri sendiri dan dapat men-takhsisi nass.

Al-Ghazali tidak secara tegas menyatakan bahwa maslahah mursalah hanya berlaku pada muamalah/adat, tidak pada ibadat, sebagaimana penegasan asy-Syatibi dan at-Tufi. Berdasarkan semua percontohan maslahah mursalah yang diungkapkannya dalam keempat kitabnya (al-mankhul, asas alqiyas, syifa' al-galil dan mustasfa) al-Ghazali juga berpendirian bahwa maslahah mursalah tidak berlaku pada ibadat. Semua percontohan yang disajikan itu diluar masalah ibadat.

\footnotetext{
ملائمة لتصرفات الشرع 59
} 
Pertama, memiliki semangatnya sebagai tokoh pembaruan hukum Islam yang luar biasa. Mayoritas Syafi'iyah dikenal sebagai kelompok yang tidak menerima maslahah mursalah. Akan tetapi, al-Ghazali yang muncul ditengah-tengah mereka berani tampil memproklamirkan dirinya secara tegas menerima maslahah mursalah. Bahkan Imam Syafi'i (w.204 H) sendiri tidak secara jelas menyebutkannya sebagai salah satu metode istinbath dalam risalah-nya, sehingga ada dua riwayat tentang Imam Syafi'i. Sebagian riwayat menolak dan riwayat lain menerima.

Oleh karena Imam Syafi'i menolak mentah-mentah istihsan dan maslahah mursalah itu dekat dengan istihsan, maka sebagian besar ulama mengambil kesimpulan bahwa imam Syafi'i menolak maslahah mursalah. Dalam kondisi seperti itu, al-Ghazali tampil dengan menunjukkan beberapa hasil ijtihad Imam Syafi'i yang berdasarkan maslahah mursalah. Menurut hemat penulis, apa yang dilakukan al-Ghazali ini luar biasa yang dapat dijadikan motivasi bagi para pakar hukum Islam untuk berani melakukan pembaruan hukum Islam sebagaimana dicontohkan al-Ghazali.

Kedua, pembaruan hukum Islam mesti dilakukan dengan tetap mengindahkan rambu-rambu. Pelakunya harus memenuhi kualifikasi sebagai faqih mujtahid. Cara kerja dan metodenya pun harus mengikuti aturan dan metode yang sudah baku dan diakui kebenarannya oleh para pakar hukum Islam (fuqahah dan usuliyyun). Dalam menghadapi masalah baru yang timbul ditengah masyarakat, istislah merupakan metode istinbath yang paling tepat. Ini telah teruji dan terbukti keunggulannya. Sekian banyak ijtihad para sahabat, tabi'in dan al-a'immah almujtahidun pada saat terjadi kasus baru bila diteliti, yang paling dominan ditempuh lewat metode istislah.

Untuk ini al-Ghazali telah membahas begitu dalam dan detail tentang maslahah mursalah dengan beberapa percontohan. Dari kalangan mazhab mana pun belum ditemukan seorang tokoh usul al-fiqh yang membahas maslahah mursalah secara luas dan mendetail seperti yang dilakukan al-Ghazali. Dengan demikian, bagi yang ingin melakukan pembaruan hukum Islam dapat mempergunakan istislah sebagai metodenya yang segala ihwalnya telah dibahas secara rinci oleh al-Ghazali tersebut. 
Ketiga, pandangan al-Ghazali yang moderat (tasawwut) antara mereka yang sama sekali tidak mempergunakan maslahah mursalah, seperti mazhab Zahiri, Syi'i, mayoritas Syafi'iyah dan sebagian Malikiyah, dengan mereka yang agak longgar seperti asy-Syatibi dan yang begitu berani seperti at-Tufi. Al-Ghazali membenarkan istislah untuk dijadikan metode istinbath, tetapi dengan syarat-syarat yang dapat mengendalikan pelaku pembaruan hukum Islam untuk berhati-hati, agar tidak menyimpang dari prinsip-prinsip dasar kebenaran dan keadailan hukum Islam, sehingga pembaruan hukum Islam yang dilakukannya bukan saja lebih mendekati pada kebenaran, tetapi juga akan benar-benar membawa maslahat bagi umat manusia.

Dengan mengikuti pandangan al-Ghazali yang menjadikan maslahah mursalah sebagai dalil penetapan hukum Islam, akan hanya masalah baru yang dihadapi oleh umat yang status hukumnya belum ditunjukkan oleh nass al-Qur'an dan asSunnah, dapat diketahui dan ditetapkan hukumnya. Hal ini sejalan dengan upaya pembaruan hukum Islam yang akhir-akhir ini terus digalakkan. Dengan banyak permasalahan baru yang dapat diketahui dan ditetapkan hukumnya melalui maslahah mursalah diharapkan hukum Islam akan tetap eksis dan selalu up to date, sesuai dengan tuntutan kemajuan zaman. ${ }^{60}$ Oleh karena itu, dalam artikel ini diupayakan dan disosalisasikan guna mendorong perkembangan hukum Islam di masa datang kea rah yang lebih baik dalam rangka 'izza al-Islam wa al-muslimin.

صالح لكل ومان ومكان 60 


\section{Daftar Pustaka}

Al-Albani, Silsilah al-Ahadis as-Sahihah, Beirut: al-Maktab alIslami, 1972.

Al-Amidi, al-Ihkam fi usul al-Ahkam, juz.4, Beirut: Dar al-Kutub al-'Ilmiyah, t.t.

Al-Asnawi, Nihayah al-Wusul, Beirut : Alam al-Kutub, 1982.

Al-Ghazali, al-Mustasfa min 'Ilm usul, juz.2, t.tp.: Dar al-Fikr, t.t.

Al-Hammam, Al-Kamal ibn, at-Tahrir, Juz.4, t.tp : Dar al-Fikr, t.t.

Al-Hasyimi, Sayyid Ahmad, Muhtar al-Ahadis an-Nabawiyyah, cet. Ke-12, Beirut: Dar al-Fikr, t.t.

Al-Hudari, Usul al-Fiqh, cet. Ke-7, t.tp.: Dar al-Fikr, 1981.

Al-Kalbi, Taqrib al-Wusul ila 'Ilm al-Ushul, Tahqiq Dr. AsySyanqiti, Cairo : Maktabah Ibn Taymiyah, $1414 \mathrm{H}$.

Al-Minawi, faid al-Qadir, juz.2, Cairo: Maktabah at-Tijariyah alKubra, 1938.

Al-Qardawi, Yusuf, al-Ijtihad al-Mu'asir, t.tp. : Dar at-Tauzi' wa an-Nasyr al-Islamiyah, 1994.

Ar-Razi, Fakhr ad-Din, al-Mahsul fi 'Ilm Usul al-Fiqh, cek ke-1, jilid.2, Beirut: Dar al-Kutub al-Ilmiyah, 1998.

As-Salih, Adib, Tafsir an-Nusus, juz.1, Beirut: Dar al-Jil, t.t.

As-San'Ani, Subul as-Salam, t.tp : Dar al-Fikr, t.t.

Asy-Syafi'i, ar-Risalah, cet. Ke-1, Kairo: Matba'ah al-Halabi, t.t. Asy-Syaukani, Irsyad al-Fukhul, Surabaya: Salim bin Sa'id, t.t.

Asy-Syirazi, al-Luma' fi Ushul al-Fiqh, Semarang :Toha Putra, t.t.

Badran, Badran Abu al-'Ain, Ushul al-Figh al-Islami, Iskandariyah: Mu'assasah Syabab al-Jami’ah, t.t.

Bukhari, Sahih al-Bukhari, juz.2, Beirut: Dar al-Fikr, t.t.

Dawud, Abu, Sunan Abi Dawud, juz.2, Beirut : Dar al-Fikr, t.t.

Depdikbud, Kamus Besar Bahasa Indonesia, cet. Ke-7, edisi ke2, Jakarta : Balai Pustaka, 1996.

Echols, John M. dan Hasan Shadly, Kamus Inggris Indonesia, Jakarta: PT Gramedia Pustaka Utama, 1978.

Fakhr ad-Din ar-Razi, al-Mahsul fi 'Ilm Usul al-Fiqh, cek ke-1, juz.2 (Beirut: Dar al-Kutub al-Ilmiyah, 1998), 39.

Hanbal, Ibn, al-Musnad, juz.2, Beirut: al-Maktab al-Islami, 1978.

Hassan, Husain Hamid, Nazariyyat al-Maslahah fi al-Fiqh alIslami, t.tp : Dar al-Nahdah al-'Arabiyyah, 1971.

Khallaf, 'Abd Wahhab, Masadir at-Tasyri al-Islami fima la Nassa fih, Kuwait: Dar al-Qalam, t.t. 
Musa, Yusif, Tarikh al-Fiqh al-Islam, t.tp.: Dar al-Ma'rifah, t.t.

Sa'ad, Bustami Muhammad, Mafhum Tajdid ad-Din, Kuwait : Dar ad-Da'wah, t.t.

Sy-Syatibi, al-Muwafaqat, juz.4, t.tp.: Dar al-Fikr, t.t.

Zaki ad-Din Sya'ban, Ushul al-Fiqh, cet. Ke-1, t.tp: Matba'ah Dar at-Ta'lif, t.t. 